\title{
TRINITARIESE VERBEELDING EN POST- APARTHEID SUIDER-AFRIKA: FRAGMENTE OOR DOGMATISERING EN DOSERING
}

\author{
R. Venter ${ }^{1}$ \\ ABSTRACT \\ TRINITARIAN IMAGINATION AND POST- \\ APARTHEID SOUTHERN AFRICA: FRAGMENTS \\ ON DOING DOGMATICS AND TEACHING
}

\begin{abstract}
A proposal is made about the teaching of Dogmatics in Southern Africa. An alternative teaching practice is required by the radical social, intellectual and theo-ecclesial changes. New sentiments have emerged which contributed to a change in the conception of the dogmatological task. The dogmatician linguistically constructs a symbolic universe that exerts an ethical impact. The notion of a "trinitarian imagination" is espoused to articulate the entire Christian vision from the reality of God's trinitarian identity. The existence of possible challenges to such a proposal is acknowledged. When applied to the classroom it implies that students should be mentored to acquire the skill of trinitarian rhetoric; that the selection of study material has become tremendously problematic; and finally, that learning should become much more experimental. The conviction is expressed that such a trinitarian orientation could contribute in a positive way to the Southern Africa context.
\end{abstract}

\begin{abstract}
ABSTRAK
Die artikel maak 'n voorstel oor die dosering van Dogmatiek in Suider-Afrika. 'n Nuwe klaskamerpraktyk word vereis deur ingrypende sosiale, intellektuele en kerklikteologiese veranderinge wat plaasgevind het. Nuwe sentimente het na vore getree wat vereis dat die dogmatologiese taak anders verstaan moet word as vroeër. Die dogmatikus konstrueer taalmatig 'n simboliese universum wat 'n etiese impak het. Sentraal in die argument staan die voorstel van 'n trinitariese verbeelding as projek om die volle Christelike visie te artikuleer vanuit die werklikheid van God se trinitariese identiteit. Erkenning word gegee aan die besondere uitdagings waarvoor só 'n konsep te staan kom. Toegepas op klaskamerpraktyk impliseer dit dat studente begelei moet word tot 'n vaardigheid in trinitariese retoriek; dat leerstofseleksie uitermate
\end{abstract}

1 Dr. R. Venter, Navorsingsgenoot, Departement Dogmatologie, Universiteit van die Vrystaat; en Justo Mwale Theological College, Lusaka, Zambië. E-pos: rventer@zamnet.zm 
geproblematiseer word; en dat leerervarings veel meer eksperimenteel raak. Die oortuiging is dat 'n trinitariese oriëntasie 'n konstruktiewe bydrae kan lewer tot die SuiderAfrikaanse konteks.

Hoe behoort Dogmatiek ${ }^{2}$ in Suider-Afrika gedoseer te word? Hoe sou gedink kan word oor die artikulering van leeruitkomste, oor die identifisering van leerinhoude en oor die ontwerp van leerervarings? As dosent van Dogmatiek is ek self intens bewus hoe maklik dit is om klaskamerpraktyk deur die volgende te verteken: opvoeding as oordrag van 'n stabiele kanon van feite wat studente hoofsaaklik kognitief absorbeer deur memorisering; 'n onsensitiwiteit vir die perspektiwiese en ideologiese aard van die produksie van kennis, en die sosiale impak daarvan; en 'n nalating om studente se kreatiewe uniekheid in ag te neem. Die artikel wil tentatief — daarom die verwysing na "fragmente" - 'n voorstel aanbied oor die dosering van Gereformeerde Dogmatiek in Suider-Afrika wat erns wil maak met sosiale en intellektuele verskuiwings, 'n verantwoorde opvoedkundige benadering, en, hopelik, 'n uiteindelike konstruktiewe effek op die publieke aspek van die teologie. Enige doseer-aanpak berus op 'n verstaan van die dogmatologiese taak en vereis dat daar eers redelik volledig, binne beperkte bestek, hieraan aandag gegee moet word. Om dit te kan doen, moet daar eers kennis geneem word van ingrypende verandering in ons tyd en wat die effek daarvan op dogmatologiese refleksie is.

\section{INGRYPENDE VERANDERING}

Daar kan maklik geargumenteer word dat die dosering van Dogmatiek al klaar so uiteenlopend en vernuwend is of dat die beoefening van teologiese dissiplines gevrywaar is van beïnvloeding deur sosiale verandering sodat geen nuwe besinning nodig is nie. Dit is my oortuiging dat 'n uitdruklike opgaaf om van hierdie taak rekenskap te gee wél nodig is, en dat sekere veranderinge so radikaal is, dat geen opvoedkundige praktyk en teologiese vakgebied onaangeraak kan bly nie. Dit sou 'n illusie wees om te wil voortgaan asof niks ingrypend verskuif het nie en asof daar geen alternatiewe wyse van doen is nie;

2 "Dogmatiek" en "Sistematiese Teologie" word in hierdie artikel as sinonieme gebruik, hoewel nuanses in assosiasie onderskei kan word. 
asof Dogmatiek a-temporeel is en die oordrag van 'n geslote korpus van onveranderde geloofsinhoude behels. ' $n$ Verantwoordelike beoefening van 'n vakwetenskap sal juis van die omstandighede en voorwaardes waaronder dit plaasvind, rekenskap gee. In 'n sin word so 'n opgaaf met 'n gevoel gedoen van déjà vu: die terme en insigte is oorbekend. Die vraag is egter of die diskoers die werklike doseringspraktyk van Dogmatiek geráák het en of alles gerieflikheids- en veiligheidshalwe gerangeer is na 'n afskeep-kursus oor Apologetiek of een oor nuwe tendense. Na Kuhn en Foucault ${ }^{3}$ sou bloot die oningeligte die paradigmatiese of epistemiese bepaaldheid van akademiese refleksie ontken. Iets sosiaal-polities, intellektueels en kerklik-teologies het gebeur wat nie ontken kan word nie - iets wat die bedryf van Dogmatiek en die dosering daarvan wesentlik raak. Om dit onder een noemer te bring, is bykans onmoontlik. Om van "post-moderniteit", "postkoloniale era" of "globalisasie" te praat, is bloot heuristiese pogings om iets van die tydsgewrig kortweg te etiketteer.

Sosiaal-polities het mag verskuif en is inklusiewe demokrasie verbreed. Alle Dogmatiek in Suider-Afrika ís voortaan post-Apartheidsteologie. Hiermee word nie net 'n chronologiese predikaat aangedui nie, maar word 'n spesifiek materiële taak geïndentifiseer: opgaaf van aandadigheid, en spesifiek van die dinamika van religieuse legitimering en van die sosiale effek van 'n bepaalde geloofskonstellasie; terselfdertyd die uitdaging tot konstruering van 'n nuwe simboliese universum en ruimte vir 'n alternatiewe konfigurasie van menslike verhoudinge. Dat hier 'n groter historiese werklikheid ter sprake is, moet verreken word: die ontdaning van die negentiende-eeuse kolonialisasie. ${ }^{4}$ As postapartheidsteologie is Dogmatiek ook post-koloniaal en kan dit nie ontsnap van die "brutal encounter of the African world with European modernity" (Eze 1997:4) nie. ${ }^{5}$ Hierdie politieke werklikhede raak

3 Die werk van Kuhn (1970) en Foucault (1970) met die begrippe "paradigma" en "episteem" is oorbekend in hierdie verband.

4 Kyk byvoorbeeld Hobsbawm (1994) vir hierdie sogenaamde "End of Empires" (hfs 7).

5 Die vraag kan selfs gesuggereer word of hier nie 'n derde - en nog omvattender — historiese werklikheid haar voltrek nie: die taning van die Westerse beskawing en die opkoms van die nie-Westerse. Kyk in hierdie verband die opspraakwekkende boek van Huntington (1996). 
Dogmatiek wesentlik en dit kan nie ontsnap van die interaksie tussen kennis, mag en sosiale impak nie. Dat Dogmatiek gestempel is deur politieke werklikhede en dat dit op haar beurt daartoe bygedra het, is nie juis moeilik om aan te toon nie. Dat dit op 'n nuwe drempel staan sedert 1994 is duidelik: hoe gaan dit voortaan gestempel word en watter rol gaan dit speel?

Die intellektuele horison het ewe dramaties verskuif met die kristallisering van die post-moderne toestand en gepaardgaande diskoers. ${ }^{6}$ Dat Dogmatiek haar eksplisiet moet verantwoord vis-à-vis die veronderstellings van moderniteit, het akuut nodig geword. Verskeie ingeligte teoloë besef dat veel meer op die spel is as die reduksie tot die slagspreuk "alles het nou relatief geword", maar dat die gangbare verstaan van rasionaliteit as sodanig en al haar konstituerende meelopers onhoudbaar geword het. Dit is haas onmoontlik vir Dogmatiek om die sentimente wat allerweë in wetenskapsbeoefening begin posvat, die rug toe te keer. Dit het 'n hele bedryf geraak om moontlike reaksies op die post-moderne toestand te suggereer. ${ }^{7}$ Vir die basiese tese van hierdie artikel is dit belangrik om te wys op drie belangrike insigte: die taalmatige aard van die menslike bestaan, volgehoue aandag vir die "Ander", en 'n "gnoseological humility" (sien Scanlon 1999: 229, 231, 233). Die sogenaamde "linguistic turn” in die filosofie ná 'n fokus op metafisika en epistemologie (Scanlon 1987), en 'n verstaan van die gesig van post-modernitieit as "the face of the other" (Tracy 1994:108) ${ }^{8}$ dwing die Dogmatiek tot selfondersoek van haar grondoortuigings. Die post-moderne moment skep 'n selfbewustheid van die kompleksiteit van dogmatisering en die dosering daarvan wat vroeër nie aanwesig was in 'n modernistiese atmosfeer van epistemologiese hubris nie.

6 Nuansering is uiters belangrik wanneer oor post-moderniteit gepraat word; hier kan gerieflikheidshalwe onderskei word tussen 'n toestand, 'n aantal praktyke, 'n kulturele diskoers, 'n ingesteldheid en 'n wyse van analise; kyk Usher \& Edwards (1994:7). Vir 'n uitstekende resente kartering en aanduiding van die implikasies vir teologie, sowel as goeie literatuur, kyk Vanhoozer (2003b).

7 'n Onlangse bundel opstelle (kyk Vanhoozer 2003a), gee 'n handige insae hierin.

8 Die seminale invloed van veral Wittgenstein en Levinas onderskeidelik verdien hier erkenning. 
Kerklik-teologiese verwikkelinge in veral die tweede deel van die twintigste eeu vertoon uiteraard 'n ryke verskeidenheid. Vir Dogmatiek in die Suider-Afrikaanse konteks is veral twee ontwikkelinge belangrik: die verbysterende groei van nie-Westerse en PentekostalistiesCharismatiese Kerke. 'n Uitstaande kenner soos Walls (2002:119) gaan selfs so ver as om te beweer: "We may need to look at Africa today in order to understand Christianity itself." 'n Westers-georiënteerde Dogmatiek kán net nie langer deug in Suider-Afrika nie. Terselfdertyd wys 'n ander gesaghebbende waarnemer, Cox (1999:141), op die mite van sekularisasie en op die voorstanders van Pentekostalisme as "refugees from the multiple tyrannies of both tradition and modernity". Cox se aanvoeling dat hierdie tendens 'n barometer is van die massiewe transformasie in die breër globale samelewing, moet op een of ander wyse in die Dogmatiek aan die bod kom. Op een of ander wyse het die Dogmatiek, as uitdrukking van die inhoud van geloof, te kort geskiet en nie mense se diepste behoefte aangespreek nie. Verder is dit bloot nie moontlik om teologiese ontwikkelinge in dieselfde periode onder een noemer te bring nie. Vir die onderhawige bestek is veral twee sake van kardinale belang: teologieë van die "Ander" (d.w.s. waar geslag, ras, klas, kultuur die basiese optiek bied), ${ }^{9}$ en die terugkeer van die Godsvraag en meer spesifiek die renaissance van die triniteitsleer. ${ }^{10}$ Op beide verwikkelinge word teruggekeer in die artikel met die vaste oortuiging dat iets van so 'n radikale aard plaasgevind het dat vroeëre Dogmatiek tot 'n groot mate onvoldoende gelaat word.

Die uitwys van hierdie drie groepe van verandering geskied met die wete dat die horison veel meer kompleks is as dié aantal wat uitgelig is, ${ }^{11}$ en dat die impak daarvan op vakwetenskaplike beoefening sorgvuldige refleksie vereis vir potensiële koersverandering. Vir die onderhawige bestek van die artikel is dit voldoende om te beklemtoon dat ingrypende veranderinge plaasgevind het - veranderinge wat nie ontken kan word nie. Wat wél kontensieus is, is of hierdie

9 Twee goeie werke wat 'n oorsig bied van die algemene ontwikkelinge is Ford (1997) en Baum (1999).

10 Kyk Tracy (1994a) en Thompson (1997).

11 'n Ensiklopediese werk soos dié van Watson (2000) gee 'n indruk van dié kompleksiteit. 
veranderinge tradisionele dogmatologiese handelinge fundamenteel dwing tot transformasie. Hiervan is ek wel oortuig.

\section{VERREIKENDE IMPAK}

Die moontlike impak van hierdie geïdentifiseerde ontwikkelinge moet nader aangedui word. Ek wil hier in besonder op twee aspekte wys - die persoon van die dogmatikus en die kenmerke van die dogmatiese aktiwiteit — wat bykans mateloos deur die veranderinge geproblematiseer en gekompliseer is.

Die dood van die wit man as dogmatikus in Suider-Afrika het klaarblyklik aangebreek. Die dogmatikus bewoon nie meer 'n neutrale akademiese ruimte nie, maar het 'n simboliese draer geword van perspektiewe, waardes en magsbelange. Geloofwaardigheid, nie net in terme van akademiese navorsing nie, maar in terme van ras, kultuur, geslag en klas het na vore getree. In Suider-Afrika met haar groot verskeidenheid is hierdie realiteit uiters aktueel en is drastiese transformasie reeds onderweg. Konflik, bedreiging en uiteindelike verruiming gaan waarskynlik die toneel kenmerk. Om verandering hier te weerstaan, is bloot loopbaan-opportunisties. Die wit man as gereformeerde dogmatikus staan voor ' $n$ besondere uitdaging om sy geloofwaardigheid te vestig. Benewens hierdie demografiese impak word die persoon van die dogmatikus verder geraak deur die verstaan van sy/haar rol. Die sosioloog Bauman (1987) se onderskeid tussen die intellektueel as "legislator" en "interpreter" is hier uiters toepaslik. Die dogmatikus is nie meer 'n outoritêre figuur wat uitsprake maak met universele geldigheid nie, maar is veel meer 'n fasiliteerder van kommunikasie tussen diverse deelnemers. Veral by dosering is hierdie onderskeid relevant en verdien Bauman se gedagtes noukeurige aandag van dogmatici. ${ }^{12}$ Die filosoof Kearney (1988:13) se idee van 'n bricoleur as iemand wat met fragmente ${ }^{13}$ van betekenis speel, is ook in 'n sin ter sake. Geen dogmatikus verteenwoordig meer alle perspektiewe nie; 'n openheid

12 Sy ontleding van moderniteit en post-moderniteit, die veranderende rol van die intellektueel, en die gedagte van die "interpreter" en "communication between systems of knowledge" (1992:22) kan met vrug benut word.

13 Tracy het die belangrikheid van die kategorie "fragmente" vir teologie goed ingesien; kyk as voorbeeld sy werk van 1999. 
vir die Ander behoort ' $n$ basiese ingesteldheid te wees. Fasilitering van 'n intersubjektiewe gesprek tussen verskillende perspektiewe vorm deel van die nuwe rol van die dogmatikus. ${ }^{14}$

Die kenmerke van die dogmatiese aktiwiteit vra om groter artikulasie. Benewens die vermelde tentatiewe en perspektiwiese aard, word Dogmatiek voortaan gestempel deur 'n sterk etiese bewussyn, 'n sensitiwiteit vir die metaforiese en performatiewe funksies van taal, en 'n aanvaarding van die bibriede ${ }^{15}$ aard van aansprake. Al vier hierdie kenmerke is bykans onvermydelik, omdat die dogmatologiese aktiwiteit wesentlik 'n re-presenterende is. Om die inhoudelike van die Christelike geloof weer te gee, moet die inhoudelike van die Bybel, tradisie (in die sin van konfessionele), ervaring en konteks in hul rykheid teenwoordig gestel word. Daar is geen wyse hoe dit sonder 'n besondere perspektief, sonder taal, sonder die etiese, en sonder nuwe konfigurasies kan geskied nie. Die dogmatiese taak word selde — indien ooit - as representasie beskou. As kategorie wat veral in die postkoloniale diskoers haar verskyning gemaak het, ${ }^{16}$ kan dit heuristies vrugbaar aangewend word in die Dogmatiek om sodoende die kompleksiteit van die aard van die aktiwiteit aan te dui. Nuwe sentimente is aanwesig - sentimente waarvan die verdienste moeilik ontken kan word. Wat meestal gemis word by tradisionele omskrywings van die taak van Dogmatiek, ${ }^{17}$ is 'n erkenning en bewustheid van die komplekse aard van die aktiwiteit. Die oënskynlike eenvoud en erns van die definisies verbloem bloot ideologiese vooroordele en potensiële sosiale effekte. In 'n nuwe tydsgewrig is daar weinig ruimte

14 Kyk in hierdie verband die tersaaklike werk van Schipper (1999) wat pleit vir 'n "culture of interdiscursivity". Sy sny spesifiek die probleem van Self en Ander aan en die moontlikheid om oor die Ander te (mag) spreek.

15 Dit was veral Bhabha, as post-koloniale denker, wat aandag gevestig het op "hybridity" as aanduiding van — veral — diaspora-identiteit. Mutatis mutandis kan Dogmatiek veel hiervan leer. Kyk sy 1994 werk.

16 Kyk die seminale werk van Said (2003).

17 Byvoorbeeld Van Genderen \& Velema (1992:26) wat beweer:

De Dogmatiek is de theologische wetenschap die op systematische wijze spreekt over wat God in zijn Woord geopenbaard heeft, en die de leer van de kerk heeft te toetsen aan de Heilige Schrift, daarop te funderen en in het licht daarvan te interpreteren. 
vir hierdie bedrieglike onskuld; die dogmatikus moet van sy/haar waardes en belange eksplisiet rekenskap gee. Niemand spreek neutraal of objektief nie. In Suider-Afrika sal die etiese ${ }^{18}$ - materieel gesproke - in 'n post-apartheidsera wentel om openheid vir inklusiwiteit en verdraagsaamheid teenoor pluraliteit. Verder sal die dogmatikus bewustelik moet opereer met 'n bepaalde taalbeskouing, veral of alle taal bloot letterlik en informatief is, en of - ook Bybelse en dogmatologiese - taal veel-dimensioneel is. In finale instansie stel die hibriede aard van die aktiwiteit die teoloog waarskynlik — intellektueel gesproke - voor een van die moeilikste uitdagings. Die maklikste uitweg is om Barth, Gutiérrez, McFague, Cone, Oduyoye, Bediako te rangeer tot êrens in die gebruiklike Apologetiek of nuwe tendense, of die Afrika-Teologie aan die Missiologie te oorhandig. So word 'n materiële interaksie gerieflikheidshalwe ontduik. Die uitdaging is om hierdie insigte materieel te integreer. Of die gebruiklike koherensie ten alle koste gehandhaaf moet word, bly 'n ope vraag. 'n Eklektiese en hibriede Dogmatiek kan waarskynlik 'n alternatief wees. ${ }^{19}$

\section{KONSTRUKSIE VAN SIMBOLIESE WÊRELD}

Dit is 'n vraag of 'n post-apartheid en post-moderne verstaan van die dogmatologiese taak — formeel gesproke — wesentlik anders is. Die ontwikkeling van verskeie vakdissiplines soos filosofie, hermeneutiek, linguistiek en literatuurwetenskap, kulturele antropologie, kennissosiologie, retoriek en post-koloniale studies het waarskynlik tot die ontwikkeling van 'n algemene begrippe-arsenaal bygedra wat die dogmatikus in staat stel om die aard van sy/haar taak met veel groter sofistikasie te presiseer. Die tekortkoming van die definisie van byvoorbeeld Van Genderen en Velema (voetnoot 17) is nie wát dit sê nie, maar wat dit verswyg. Om kortweg te beweer die taak van die Dogmatiek is om die inhoud van die Christelike geloof volgens die Bybel uit te druk, is volledig aanvaarbaar. Maar juis hierdie oënskynlik simplistiese taak het onmeetlik kompleks geraak; daarvan is die

18 Die artikel van Schüssler-Fiorenza (1988) en haar basiese tese oor die sosiale effek van navorsing behoort voortdurend deur die dogmatikus in gedagte gehou te word.

19 Kyk Rorty (1998:10 voetnoot 5) se humoristiese opmerking oor sy posisie as sinkretis! 
navorser in 'n nuwe era intens bewus. Anders gestel: 'n kennis van die inspelende faktore het drasties toegeneem — iets wat vereis dat hierdie eenvoudig geformuleerde taak met groter helderheid bepaal moet word. Wat in die vorige paragraaf as representasie beskryf is, moet verder beskryf word. Ek is oortuig dat die aanwending van die volgende begrippe tot 'n deegliker verantwoording kan lei van wat die dogmatologiese taak behels: konstruksie, linguïsties-simboliese universum, kontingente diskoers, performatiewe funksie, retoriese verbeelding, geïnterpreteerde ruimte.

Die beweging van die Bybelse teks na die dogmatiese teks is moontlik — ken-teories — deur die vermoë van die menslike verbeelding, en geskied taalmatig. ${ }^{20}$ Die uiteindelike produk is nie ' $n$ blote weergee van die Bybelse teks nie, maar 'n nuwe linguïstiese konstruk $^{21}$ opgebou deur die kanons van die gangbare retoriek. ${ }^{22}$ Hierdie konstruk is niks minder nie as 'n simboliese wêreld wat deur die dogmatikus opgerig word nie. Juis omdat, eksistensieel gesproke, van die mees fundamentele vrae, byvoorbeeld oor God, skepping, sonde, verlossing en bestemming ter sprake kom, vind hier 'n ambisieuse en omvattende gebeure plaas. Met ander woorde: die dogmatikus skep deur interpretasie $\mathrm{e}^{23}$ ' $\mathrm{n}$ ruimte vir bewoning. Om die metafoor te forseer: met die boustene van die Skrif, die tradisie, die konteks, enso-

20 Lindbeck (1984) is allerweë bekend vir sy kultureel-linguïstiese benadering van leerstellings.

21 Kaufmann (1979) het veel gedoen om die aandag te vestig op die konstruktiewe aard van teologiese werk.

22 Dat die dogmatologiese aktiwiteit argumentatief is, is vir lank vergeet. Die terugkeer en oplewing van Klassieke Retoriek is een van die belangrike verwikkelinge van die afgelope paar dekades. Veral die werk van Cunningham (1990/1) verdien hier vermelding.

23 Die naïwiteit van sommige tradisionele opvattings, soos Van Genderen en Velema (1992:20), tree juis hier na vore waar daar met groot instemming met Polman gemaan word om nie in die ban van die hermeneutiek te kom nie. Dit is juis hierdie illusie dat die dogmatikus hom/haarself kan vrywaar van die besmetting van die interpretatiewe waarvan onherroeplik afskeid geneem moet word. Die menslike kognitiewe aktiwiteit is deurgaans interpretatief. 
voorts word 'n gebou opgerig. Die gekonfigureerde ruimte ${ }^{24}$ inhibeer, vergemaklik, nooi uit en moedig aan tot bepaalde handelinge. Juis hierdie effek en impak van die dogmatiese universum is van kardinale belang. Dit is moontlik om, juis op Skrifgronde, 'n priesterlike, ${ }^{25}$ wysheids-, juridiese ${ }^{26}$ of apokaliptiese wêreld te skep — wêrelde wat die bewoners behep maak met besmetting, met orde, met skuld of met konflik. Interessante vrae kan in hierdie verband geopper word: watter tipe wêreld het tot die religieuse legitimering van apartheid bygedra? Wat is die karakter van die tradisionele gereformeerde simboliese wêreld; en verder: is dit inherent oppressief en intolerant? Watter tipe universum is nodig vir 'n nuwe bedeling? Kan stabiele en geïntegreerde wêrelde geskep word te midde van 'n verskeidenheid van perspektiewe?

Een aspek behoort duideliker aan die orde te kom: die fundamentele en omvattende aard van hierdie universum wat die dogmatikus skep. Dit kan die karakter van 'n dogmatiese leerstuk ook nader belig. Indien die tradisionele loci geanaliseer word, is dit duidelik dat meer op die spel is as blote sistematiserings- of klassifikasiebeginsels. Elkeen spreek wesentlik die mees fundamenteel menslike vrae aan. 'n Fenomenologiese blik op hierdie leerstukke lig dit maklik uit: by openbaring kom die vraag na die gronde van waarheid ter sprake; by die godsvraag die vraag na transendensie; by skepping, oorsprong; by voorsienigheid, kousaliteit; by sonde, kwaad; by Christologie en Pneumatologie, bemiddeling van transendensie; by kerk, gemeenskap; by sakramente, rituele en simbolisering; by eskatologie, hoop en bestemming. Alhoewel baie vereenvoudig weergegee, kan hierdie verstaan van die taak van die dogmatikus help om beide aktueel te spreek en om

24 Dit is opvallend hoe min dogmatici opereer met die kategorie “ruimte'. In die post-modernistiese en post-koloniale diskoers word veel hiervan gemaak en ek reken dit kan allerlei perspektiewe vir teologie open. Kyk byvoorbeeld standaardwerke in hierdie verband: Lefebvre (1991) en Soja (1996). Een uitsondering onder teoloë is waarskynlik Moltmann wat dit in sy skeppingsleer en eskatologie ter sprake bring.

25 Kyk die insiggewende opmerkings van Brueggemann (1997:195vv.) oor houdings teenoor homoseksuele en die reinheidstrajek van die Ou Testament.

26 Kyk byvoorbeeld Schilder (1987) wat wys op die verband tussen Gereformeerde leer en depressie. 
in gesprek te tree met alternatiewe interpretasies van die werklikheid, byvoorbeeld dié van die Tradisionele Afrikagodsdiens, 'n agnostieshumanistiese, Islamitiese, ensovoorts. Struktureel gesien bied elkeen hiervan antwoorde op dieselfde vrae. Die gevaar is dat die dogmatikus vasgevang kan bly in die projek om totaliserende sisteme op te stel. Indien die vier vermelde eienskappe van die dogmatologiese aktiwiteit met erns bejeën word, kan daar aan hierdie aanklag ontkom word. Om omvattend tentatiewe en perspektiwiese antwoorde argumentatief te bied met 'n openheid vir die wisselwerking tussen mag, kennis en taal, is iets anders as dit waarteen Lyotard (1984) agiteer. So verstaan, kan die Dogmatiek nog steeds lokaal wees; dit behoort tewens juis hierdie kontingente spreke te wees.

\section{CHRISTELIKE IDENTITEIT EN TRINITARIESE RENAISSANCE}

Die argumentent tot dusver skep die indruk dat die Dogmatiek volledig reaktief oorgelewer is aan sosiale, intellektuele en kerklike verandering. Geensins! Die identiteitsvraag kan eers aan die orde kom nadat die horison van besinning, die nuwe toestande waarbinne refleksie plaasvind, verken is. Om die dogmatikus te wil saniteer of te immuniseer hierteen, met die pretensie van transendering, rus op 'n massiewe illusie. Die volledige historiese ${ }^{27}$ bepaaldheid van spreke is waarskynlik een van die groot winspunte van die hermeneutiek in die twintigste eeu.

Die vraag wat behandel moet word, is dit: wát maak dogmatologiese spreke Christelik? Wat maak die konstruering van 'n Christelik interpretatiewe universum spesifiek Christelik? Die antwoord is eenvoudig: deur konsekwent vanuit die identiteit van die Christelike God te dink; dit wil sê, deur trinitaries te besin. Hierdie stelling is van enorme belang en vorm die hart van die argument. Die dogmatikus se bydrae word juis hier gevind: om te midde van die verandering die werklikheid volledig trinitaries te interpreteer.

Wie ook al 'n oorsig van die teologie in die twintigste eeu aandurf, kan een uitstaande kenmerk nie mis nie — die sogenaamde 
renaissance van die triniteitsleer. 'n Eeu wat die oorwinning van moderniteit en sekularisasie oor geloof moes beklink, het ironies anders verloop. Nie net het die vraag na God met krag na die agenda teruggekeer nie, maar die vraag na die spesifiek Christelike belydenis oor God het sentraal geword. Die posisie van die leerstuk in die breë opset van die Dogmatiek en die radikale verskuiwing wat plaasgevind het, word programmaties deur Schleiermacher (1928[1976]:738-751) en Barth (1975:295-389) verteenwoordig. Die trinitariese belydenis word nie langer gemarginaliseer tot 'n nawoord nie, maar het die fundamentele optiek geword wat aan die begin van alle materiële refleksie staan. ${ }^{28}$ Hierdie ingrypende insig van Barth ${ }^{29}$ het teologies eers begin deurwerk tydens die laaste twee, drie dekades van die eeu. Van die mees gerespekteerde teoloë in hierdie periode, oor 'n breë spektrum van tradisies, ${ }^{30}$ het die belangrikheid van trinitariese denke ingesien. 'n Hele reeks van uitstaande en opwindende werke getuig van hierdie nuwe belangstelling. ${ }^{31} \mathrm{Nie}$ net word die triniteit beklemtoon as die grammatika van spreke oor God in 'n Christelike sin nie (Williams 2000:129), maar 'n hele reeks van kardinale insigte kom onder die loep. ${ }^{32}$ Van die belangrikste diskussies wentel om 'n herwaardering van die nalatenskap van denkers soos Augustinus en die Kappadosiërs, die relatiewe sterk en swak punte van die Oosterse en Westerse tradisies, die verhouding van die immanente en die ekonomiese triniteit,

28 Barth (1975: 303) sê uitdruklik:

In giving this doctrine a place of prominence our concern cannot be merely that it have this place externally but rather that its content be decisive and controlling for the whole of dogmatics.

29 In Rooms-Katolieke kringe moet gewag gemaak word van Rahner; veral sy 1970/ 1997 werk het groot impak gehad. Ironies het hy sy eie insigte nie konsekwent toegepas nie - iets wat gevolglik sy status as trinitariese denker verduister.

30 Byvoorbeeld Von Balthasar, T.F. Torrance, Moltmann, Pannenberg, Jüngel, Jenson, en Gunton.

31 Buiten etlike werke deur bogenoemde teoloë, kyk byvoorbeeld dié van LaCugna (1991); Kasper (1983); Boff (1988) en Cunningham (1998).

32 Vir 'n goeie behandeling van die ontwikkelinge, kyk byvoorbeeld Cunningham (1995); O’Collins (1999); Olson \& Hall (2002); Peters (1993) en Thompson (1994). Waarskynlik die beste en indringendste werk is die onlangs verskene studie van Grenz (2004). 
alternatiewe ontologieë vir Griekse substansiedenke, die belangrikheid van die kategorieë "relasionaliteit" en "perigorese", alternatiewe vir of meer bevredigende verstaan van die persoonsbegrip, die impak van temporaliteit en inkarnasie op tradisionele sieninge oor God en veranderlikheid/lyding, die filioque-vraagstuk en die dilemma van inklusiewe taalgebruik. 'n Groot verskeidenheid teoloë van verskillende Christelike tradisies en van uiteenlopende kontekste het nie net die belangrikheid van die triniteit begryp nie, maar ook die potensiaal van hierdie sentrale Christelike simbool om betekenisvol en konstruktief 'n bydrae te lewer tot die publieke diskoers oor die vraagstukke van ons tyd raakgesien. Ek wil by hierdie teologiese tendens aansluit en die trinitariese belydenis pertinent betrek by die gesprek oor 'n post-apartheidsteologie en post-moderne teologie. ${ }^{33}$

Waaroor dit sentraal by die trinitieit handel moet duidelik, alhoewel erg reduserend, binne 'n bestek van hierdie aard verstaan word. Die trinitariese verstaan van God ís die spesifiek Christelike verstaan van God. Dit is nie 'n leerstuk bykomend by 'n ander meer basiese konsepsie van God nie (Pannenberg 1991:53). Die triniteit som op wat teologies van God gesê kan word (Schwöbel 1995:4). Meer materieel lê Jenson (1995:40, 42) klem daarop dat die punt van trinitariese teologie is dat die Bybelse verhaal van God en die mens wáár van God in homself is; die lewe van God word gestruktureer deur relasies waarvan die inhoud 'n narratief is. Lacugna (1991:243) som die basiese oortuiging van die nuwere trinitariese teologie op: "Trinitarian theology is par excellence a theology of relationship". Hierby sluit Gunton (1997:60) aan en spel die implikasies uit: "The development of the doctrine of the Trinity was the creation ... of a distinctively Christian ontology". Juis as "ultimate ground and meaning of all reality" (Kasper 1983:234) is die triniteit "about life, life before God, with one another and in the world" (Gunton 2003:11).

33 Cunningham (2003:187) praat pertinent van "a postmodern theology of the trinity" en behandel insiggewend twee kontrapuntale bewegings: hoe postmoderniteit en trinitariese diskoers mekaar wedersyds (kan) beïnvloed. 


\section{TRINITARIESE VERBEELDING EN DIE ONVOLTOOIDE TAAK}

Nie net is die belangrikheid van die triniteit in die laat twintigste eeu herwin nie; veel mér het ter sprake gekom en veral twee werklik positiewe verwikkelinge is onderweg waarvan deeglik kennis geneem behoort te word. Daar is aandrang dat die hele Christelike visie in haar onderskeie elemente, dit wil sê leerstukke, trinitaries deurdink moet word. Verder word daar gepoog om op die mees diepgaande probleme van die dag trinitaries te reageer.

Die projek van 'n konsekwent en komprehensief trinitariese dogmatiek word veral by teoloë soos Moltmann, ${ }^{34}$ Gunton (bv. 1997 \& 2003) en Jenson (bv. 1997 \& 1999) aangetref. 'n Hele aantal van die voorste jonger teoloë is besig om trinitariese perspektiewe te open op tradisionele leerstukke; so vind ons byvoorbeeld by Grenz oor die antropologie (2001), by Vanhoozer oor die hermeneutiek (1998) en by Volf oor die ekklesiologie (1998) werk wat waarskynlik van die belangrikste is wat op die oomblik gedoen word. Hier is 'n poging om radikaal teologies te dink, nie vanuit 'n generiese godskonsep nie, maar vanuit dit wat die onderskeidelike van die Christelike teologie is: 'n spesifieke God, met 'n unieke identiteit.

'n Tweede verreikende ontwikkeling lê op die terrein van die heuristiese en retoriese aanwending van die triniteit om uitstaande probleme van ons tyd aan te spreek. Die triniteit word op kreatiewe en verbeeldingryke manier gebruik om teologiese antwoorde te suggereer vir van die diepgrypendste kontemporêre vrae: die van waarheid, ${ }^{35}$ ateïsme, ${ }^{36}$ pluraliteit, ${ }^{37}$ sosiale onderdrukking en konflik, ${ }^{38}$ geslagtelike verhoudinge, ${ }^{39}$ inter-religieuse dialoog,${ }^{40}$ ekonomie, ${ }^{41}$ en spiritualiteit. ${ }^{42}$

\footnotetext{
34 Deurgaans in al sy werk vanaf die vroeë trilogie tot in die latere sg. "Bydraes."

35 Byvoorbeeld Marshall (2000).

36 Byvoorbeeld Kasper (1983).

37 Byvoorbeeld Vanhoozer (1997).

38 Byvoorbeeld Boff (1988).

39 Byvoorbeeld D'Costa (2000).

40 Byvoorbeeld Heim (2001).

41 Byvoorbeeld Meeks (1989).

42 Byvoorbeeld Downey (2000).
} 
Buiten die opgaaf van dié verwikkelinge, is die dieperliggende dinamika van die proses wat in die teologie onderweg is, nog nie indringend ontleed nie. Vier kort opmerkings mag hier ter sake wees. Hier is ' $n$ klaarblyklike proses om die teologie onherroeplik van die Hellenistiese metafisika en van haar knelgreep op die Christelike Godsbegrip te ontworstel, en om terselfdertyd die narratiewe gestalte van die openbaring in al haar konsekwensies ernstig te verdiskonteer. Tweedens word die uitdaging aanvaar om kreatief en konstruktief argumentatief te reageer op die sosiale en intellektuele horison van die dag. Hier is 'n duidelike verruiming van die teologiese retoriek; daar is nie 'n fundamentalistiese beroep op die Skrif nie. 'n Noukeurige ontleding van die wyse van argumentasie sal onvermydelik wees. ${ }^{43}$ Derdens funksioneer die Godsbeskouing op 'n gedifferensieerde wyse. As referent tree God na vore as Agent wat daadwerklik rigting aan historiese gebeure gee; as Persoon wat in 'n ontmoeting en verbouding met die mens tree; as die Model, die Beeld, wat om etiese navolging vra en wat as simbool normatiewe invloed het; en as 'n krities-heuristiese beginsel wat op verbeeldingryk retoriese wyse aangewend kan word om moontlike antwoorde te suggereer vir fundamenteel menslike probleme. ${ }^{44}$ In finale instansie, alhoewel nie altyd erken nie, speel die teologiese verbeelding 'n deurslaggewende rol in bykans al hierdie werk. Enkele teoloë het die belangrikheid hiervan ingesien en begin pleit vir 'n positiewe en eksplisiete waardering van die verbeelding in teologisering. ${ }^{45}$

'n Dwingende argument sou uitvoerig ontwikkel kon word om die teologiese taak, wat verdere materiële presisering en reliëf bied op dit wat reeds aangesny is, as trinitariese verbeelding aan te dui. Hiermee wil erkenning verleen word aan die kreatiewe rol wat die teoloog speel om vanuit die Christelike geloof se mees sentrale simbool en

43 Murphy (1994:14) maak die insiggewende opmerking dat die gebruik van "warrants" verstaan moet word om 'n vakdissipline te bemeester. Die geldigheid van baie van die trinitariese argumente sal getoets moet word.

44 Jenson (1997:154) maak die verreikende opmerking:

It was Barth who taught postmodern theology that the doctrine of Trinity is there to be used; that it is not a puzzle but rather the framework within which theological puzzles can be solved.

45 Kyk byvoorbeeld Avis (1999) en Green (1989). 
werklikheid - God as Vader, Seun en Gees - te reageer op die vrae en probleme van die tyd. So word daar onapologeties erns gemaak met God as triniteit, maar ook realisties met die subjektiewe aktiwiteit van die teoloog. So 'n opvatting verstaan die teologie se taak as voortgaande, as dinamies, en nie as repristinering van tradisionele argumente nie.

Hoe kan die teologie positief in gesprek tree met die voortslepende probleme in Suider-Afrika? Sou pluraliteit en verhoudinge, ekonomiese hulpbronne, en respek vir lewe in haar volle antropologiese en ekologiese omvang, aangedui word as van die velde waar akute uitdagings rus, hoe kan die Dogmatiek teologies hierop reageer? Die teoloog sal juis, hoe verregaande dit mag klink, vanuit die werklikheid van die Christelike God hieroor moet besin en daarop retories moet reageer. Dít is die bydrae wat die Dogmatiek kan maak. Gelukkig vir die Suider-Afrikaanse teoloog is voorlopige navorsing reeds hieroor onderneem wat vir die spesifiek konteks aangepas kan word en verder deurdink kan word. ${ }^{46}$

\section{DILEMMAS EN UITDAGINGS}

Om die taak van Dogmatiek formeel aan te dui as die konstruering van 'n simboliese wêreld, en materieel as trinitariese verbeelding vir 'n spesifieke historiese moment in Suider-Afrika, impliseer geensins dat dit geskied met 'n blinde oog vir die reeks probleme waarvoor dit te staan kom nie. Veral drie areas lewer besondere vrae. Dit word kortliks bespreek.

\subsection{Bybelse pluraliteit}

In 'n oorsigartikel van die nuwere skool in teologie, die sogenaamde Radikale Ortodoksie wat rondom Milbank ontwikkel het, spreek Ford (2001:398) sy verbasing uit oor die feitlike afwesigheid van 'n deeglike kennisname van die Bybel deur 'n beweging met ortodokse oog-

46 Die ontwerp van 'n sosiale triniteit is uiters relevant en baie stof is beskikbaar. Kyk byvoorbeeld Thompson (1996). Veral die werk van Meeks is ter sake by die ekonomie; kyk benewens sy hoofwerk (1989) ook die een van 1980. Die stroom van werk oor "Gift" is ook hier ter sake; kyk byvoorbeeld Webb (1996). By die probleem rondom lewe kan verwys word na die werk van Gutiérrez (1991). 
merke. Hierdie kritiek van Ford is ter sake by die onderhawige argument. Twee wyses van teologisering wat beide uiteindelik tekortskiet, is moontlik. Een kan deduktief dink vanuit die triniteit sonder om die Bybelse openbaringsgetuienis te verreken; die ander kan Bybeltekste aaneenryg (sogenaamde "proof-texting") sonder 'n streng teosentriese sentrum. Die dilemma is om 'n konsekwent trinitariese optiek te behou te midde van 'n openheid vir die ryke inhoud van die Christelike kanon. Hoe om op so 'n manier te besin om dit integraal te verwesentlik is geen maklik teologiese en dogmatologiese opgaaf nie en is waarskynlik een van die mees uitstaande uitdagings vir ' $n$ verantwoordelike teologie. Aan die een kant moet 'n Dogmatiek volle uitdrukking gee aan die pluraliteit én historiese groei van intra-kanonieke tradisies, metafore, en simboliese wêrelde, ${ }^{47}$ en aan die ander kant aan 'n fundamenteel integrerende en bepalende trinitariese blik. Een moontlikheid om hierdie probleem aan te spreek, is om 'n genealogiese moment in die dogmatiese taak in te bou; so sal elke eksistensieel-fenomenologiese vraag, byvoorbeeld "hoop", binne die kanon, etlike teksture ontvang wat bepaal word deur die dinamika van God se historiese handelinge en sy volk se interpretatiewe en tradiese-vormende reaksie daarop. 'n Dogmatiek word dus gevisualiseer wat by die tradisonele loci ten minste drie hoofkategorieë van behandeling sal ontvang: 'n eksistensieel-fenomenologiese, 'n genealogiese en 'n trinitariese. Twee vaardighede word hier van die dogmatikus vereis: enersyds 'n hermeneutiese vaardigheid en andersyds 'n kreatief-verbeeldende vaardigheid. ${ }^{48}$ Hierdie uitdaging kan uitermate gekompliseer word wanneer ' $n$ bloot ensiklopediese identifisering van intra-

47 Die swakheid van baie dogmatieke is juis hier te vind: daar word met 'n a-histories nivellerende mentaliteit geopereer wat geensins uitdrukking aan hierdie interne pluraliteit bied nie. Die uiteindelike produk is 'n ongenuanseerde teologie. Kyk vir slegs twee voorbeelde van hierdie Bybelse pluraliteit Brueggemann (1997) en sy onderskeid tussen "core testimony" en "counter testimony" waar veral die wysheidstrajek in die Ou Testament ter sprake kom in onderskeid van die Deuteronomistiese; en Theissen (1999:258) se diagrammatiese voorstelling van die verskeidenheid in die primitiewe Christelike godsdiens.

48 Dis interessant hoe 'n teoloog vanuit 'n ander teologiese dissipline met beide werklikhede opereer: Brueggemann (2003:11-13; 395-397) bring kanon en verbeelding positief in jukstaposisie. 
kanonieke tradisies (wat in elk geval bykans 'n onmoontlike taak is) vervang word met 'n bewustelike keuse van bepaalde tradisies om hul effek te verhewig. 'n Bekwame teoloog sal weet wanneer 'n Johannese in plaas van 'n Pauliniese perspektief deur' $n$ bepaalde konteks vereis word.

\subsection{Identiteit en tradisie}

Het die kerk en teologie die triniteit vergeet, of was die LatynsWesterse tradisie nog nooit volledig deurdrenk van trinitariese kategorieë nie? Hierdie verontrustende vraag van Gunton (2003:5) is relevant by hierdie argument en by die uitdagings wat 'n trinitariese verbeelding skep. Dat besinning binne die horison van 'n bepaalde tradisie waaraan die dogmatikus nie kan ontsnap nie, geskied, is nie onder verdenking nie; wél of die tradisie genoegsaam trinitaries georiënteerd is of, alternatiewelik, voldoende openheid vir 'n konsekwente deurdenking van die geloofsaansprake vanuit die triniteit het. Die geval van die gereformeerde tradisie sou 'n uiters interessante gevallestudie wees. Sonder huiwering sou die waarheid van die trinitariese belydenis bevestig word; die vraag is egter of die geloofsleerstukke materieel geïnformeer word deur die spesifieke identiteit van God as trinitaries. Die plek van die triniteit in ouer standaard Dogmatiek handboeke ${ }^{49}$ beperk die triniteit as 'n formeel ortodokse belydenis binne die godsleer en belig nie die ander loci vanuit die werklikheid van God se spesifieke identiteit nie. 'n Verwante en kontensieuse vraag wat belangrik vir Suider-Afrika is, kan geopper word: watter rol het die spesifiek dominante Godsbeskouing van die gereformeerde tradisie in die teologiese legitimering van apartheid gespeel? Hierdie vraag rus op die veronderstelling dat die sentraal godsdienstige simbool van God subtiele, maar verreikende sosiale implikasies het. ${ }^{50}$ Sou die triniteit as aanduiding van God se unieke identiteit ' $n$ prominenter rol gespeel het in teologiese besinnig rondom rasse-verhoudinge, en rondom 'n kerkbeskouing, sou die geskiedenis, vir ten minste gereformeerde kerke, nie straks anders verloop het nie? Sou die gesig van die kerk as "finite echo" van die goddelike lewe (Gunton

49 Byvoorbeeld Berkhof (1939); Heyns (1978); Van Genderen \& Velema (1992).

50 Kyk byvoorbeeld Nicholls (1989). 
1997:73) nie anders daar uitgesien het nie? Die trinitariese belydenis was nog altyd 'n toetssteen van leerstellige suiwerheid vir die gereformeerde kerke, en daar word dikwels gestel dat dié tradisie teosentries is. 'n Gereformeerde Dogmatiek vir Suider-Afrika moet hierdie oortuiging en sentiment materieel radikaliseer. Die uitkoms van die toekomstige vitaliteit van dié tradisie mag heel moontlik juis hierdeur besleg word. Dat trinitariese denke intellektuele verrassings kan oplewer, moet deeglik onder oë geneem word. 'n Simboliese wêreld wat deur God se werklikheid gestempel is, is geen gemaksone om te bewoon nie; dit kan juis indruis teen alles wat gevorm is deur 'n generiese beeld van God.

\subsection{Afrika en kultuur}

Uitsprake van twee kenners van die Afrika-Christendom en teologie staan in vreemde jukstaposisie. Walls (2002:119-122), enersyds, verklaar die aanvaarding van die Christelike geloof in Afrika deur ' $n$ kontinuïteit tussen die God van die Bybel en die Afrikaverlede te poneer; Vähäkangas (2000:33), andersyds, wys op die verwaarlosing van die triniteit deur Afrikateoloë. Hierdie uitsprake sny op besondere wyse die derde stel probleemvrae aan wat die dogmatiese taak as trinitariese verbeelding konfronteer. Om die dogmatologiese taak konsekwent trinitaries te benader, beteken om dit te doen in voortdurende gesprek nie net met die Bybel, en met tradisionele identiteit nie, maar ook met die (tradisionele) Afrikakultuur. Hiermee word 'n hele reeks komplekse vrae aangespreek. Dat die kategorie "kultuur" nie langer, gerieflikheidshalwe, gerangeer kan word na die departement Missiologie toe nie, is duidelik. Dit is 'n dogmatologiese opgaaf. ${ }^{51}$ Tweedens sal die inhoudelike van hierdie uitdaging helder verstaan moet word. Niks minder is ter sprake nie as die soeke na die uitdrukking van die (trinitariese) geloof volgens alternatiewe metafisiese sisteme en rasionaliteite. Vir te lank is die Grieks-Hellenistiese substansie-metafisika en die Westers modernistiese rasionaliteit naïewelik

51 Tanner se aanname in haar werk (1997) is in 'n sin ietwat ironies: kultuur is "a new agenda" vir Dogmatiek; vir teologie en sending is dit geen nuwe agenda nie; dit was nog altyd daar. Die fragmentering in die teologiese ensiklopedie was verantwoordelik vir hierdie onhoudbare situasie. 
veronderstel as die enigste moontlikhede. Interessant genoeg word juis in die trinitariese diskoers werk onderneem wat die eensydigheid hiervan loën. ${ }^{52}$ Die werk van Charles Nyamiti as een van die min, indien nie die enigste, Afrikateoloog wat konsekwent trinitaries dink, verdien noukeurige aandag. Hy probeer terselfdertyd aan beide realiteite vashou: Afrikakultuur en triniteit. ${ }^{53}$ Sy gedagtes, byvoorbeeld, oor die triniteit as "the exemplar of all human ancestorship" (1977:48) en die Heilige Gees as "oblation or ritual offer" binne "a sort of ritual or ceremony in the immanent Trinity" (1996:53, 56 \& 60) is alleen verstaanbaar as uitdrukking van 'n nie-Westerse metafisika wat in Afrika juis sin maak. Derdens, mag die argitektoniese opbou van die Dogmatiek anders gekonstrueer word in 'n konteks waar daar nie 'n "Cartesian anxiety" (Bernstein 1983:16) bestaan oor gronde vir epistemologiese sekerhede nie, maar wel die dominante vraag wié dinge laat gebeur (Mbiti 1991:165). Wat verhinder, teoreties gesproke, 'n kontekstuele Afrikateologie wat sensitief is vir ' $n$ alternatiewe uitdrukking van rasionaliteit ${ }^{54}$ om te vertrek vanuit 'n trinitariese Voorsienigheidsleer wat teologies Christelik dink oor magte, kragte en kousaliteit?

\section{CHAOS IN DIE TEORIE VAN KURRIKULERING}

Die eerste stap om die voorafgaande fragmente — wat grondliggend is vir alle dosering en daarom eers volledig aangetoon moes word konkreet by die klaskamer uit te bring, is om die veld van kurrikulering en teorie van kurrikulering te betree. 'n Bewustelike interseksie tussen Dogmatiek en kurrikulering as vakwetenskap word selde aangetref. Dogmatici sien hulself veel eerder as navorsers en nie as opvoedkundiges nie, met die gevolg dat 'n klaaglike onkunde doseerpraktyk kenmerk. Diegene wat die veld wil betree, bevind hulself onmiddellik gekonfronteer met twee komplikasies. Daar is geen eenduidige verstaan van "kurrikulum" nie, en terselfdertyd staan die vakdissipline in hewige rekonstruksie as gevolg van postmoderniteit.

52 Kyk byvoorbeeld pogings om vanuit die prosesdenke en vanuit die Asiatiese kultuur anders oor die triniteit te dink: Bracken \& Suchoki (1997) en Lee (1996).

53 Kyk byvoorbeeld 1985, 1987, 1988, 1996, 1998, 1999.

54 Kyk byvoorbeeld die bundel van Du Toit (2002). 
Ter illustrasie kan kortliks gewys word op Kelly (1989:26vv., $48 \mathrm{vv}$., $84 \mathrm{vv}$.) se onderskeid tussen kurrikulum as inhoud, as produk en as proses. Insiggewend hier is dat elkeen van hierdie benaderings 'n bepaalde verstaan van opvoeding veronderstel: opvoeding as oordrag, as instrument, of as ontwikkeling. ${ }^{55}$ Word hierby nog die verskillende ontwerpmodelle wat bestaan, gevoeg, te wete dissipline-, leerder of probleemoriëntasie (Ornstein 1988:242-260), kom mens onder die indruk van die kompleksiteit van kurrikulering. Hierdie insigte van Kelly en Ornstein vergemaklik heuristies 'n poging om iets van die tradisionele aanpak te verstaan. Dat die onderliggende konsep van kurrikulum inhoud- en dissiplinegesentreerd was en opvoeding berus het op die oordrag van 'n stabiele kanon van kennis, is maklik om aan te dui.

Die kristallisering van 'n post-moderne era het meegebring dat die tradisionele veld van kurrikulumstudie as terminaal siek (Pinar 1979:15) of as in 'n chaotiese toestand (MacPherson 1995: 272) verklaar is. Wie in kurrikulumwaters wil vaar, vind hul weg uiters moeilik. In plaas van om te konsentreer op die breë verskuiwings, ${ }^{56} \mathrm{kan}$ dit help om die verandering spesifiek aan te dui as 'n onvergenoegdheid met die sogenaamde Tyler-rasionaal. ${ }^{57}$ Ten spyte van die oënskynlike eenvoud van die Tylermodel, lê 'n noukeurige kyk dieperliggende probleme wat modernistiese opvoedkunde kenmerk, bloot. Dit berus op 'n verstaan van die wêreld as stabiel en kontroleerbaar (Doll 1993: 52-55); dit is wesentlik waardeneutraal en sonder sosiale gesitueerd-

55 Vir'n meer gedetailleerde opgaaf van verskillende konsepsies van kurrikulum, kyk Tanner \& Tanner (1995:hoofstuk 5); veral die tabel (p. 188) bied 'n baie handige oorsig van die wisselwerking tussen 'n bepaalde verstaan van kurrikulum en die funksies wat dit speel.

56 Vir die hele vraagstuk oor opvoedkunde en postmoderniteit is die werk van Usher \& Edwards (1994) handig.

57 Tyler se invloed is baie wyd in die veld van kurrikulumstudies. Hy het vier basiese vrae geïdentifiseer wat kurrikulering moet stuur (sien 1949:1):

1. What educational purposes should the school seek to attain?

2. What educational experiences can be provided that are likely to attain these purposes?

3. How can these educational experiences be effectively organized?

4. How can we determine whether these purposes are being attained?" 
heid (Hunkins \& Hammill 1995:18, 19). Wát 'n post-moderne kurrikulum is, is nie maklik om aan te toon nie. 'n Hele reeks nuwe sentimente het na vore getree. 'n Veel groter openheid bestaan vir kompleksiteit, verdraagsaamheid van dubbelsinnigheid, en aanvaarding van onsekerheid (Slattery 1995:49). Daar is 'n wegbeweeg van die kurrikulum as finale produk; kurrikula is veel eerder "living systems that never really settle down"; daar is dan ook nie net één manier om dit te skep nie (Hunkins \& Hammill 1995:21, 22). Die post-moderne kurrikulum beklemtoon die prosesmatige karakter waar leer en verstaan gevorm word deur dialoog en deur konstruksie, en waar groter gesamentlike beplanning geskied tussen student en dosent om nie die bekende oor te dra nie, maar die onbekende te verken (Doll 1993: 155 vv., 169, 171).

\section{ALTERNATIEWE KLASKAMERPRAKTYK}

Al die voorafgaande perspektiewe moet uiteindelik neerslag vind in 'n konkrete klaskamerpraktyk. Sonder om aan Cornbleth (1990:25) se insig dat kurrikulum wesentlik 'n "contextualized social process" is, afbreuk te doen, kan die belangrikheid van die ontwerp van 'n vaksillabus $^{58}$ nie genoeg beklemtoon te word nie. Die geskrewe dokument hoef nie uitdrukking van 'n modernistiese mentaliteit te wees nie; inteendeel, dit kan juis die dosent forseer om rekenskap te gee van soveel waardes wat nooit eksplisiet geartikuleer word nie. Verder hoef dit ook nie eensydig en outoritêr aan die student voorgeskryf te word nie; dit kan interaktief ontwikkel word na 'n aanvanklike kontaksessie. Deur van die tradisionele ontwerp-komponente - te wete, leeruitkomste, leerinhoude, leerervarings en evaluering (sien Ornstein 1988:232v.) - gebruik te maak by die opstel van 'n vaksillabus, hoef ook nie uitdrukking te wees van 'n tipies Tyleriaanse rasionaliteit nie. ${ }^{59}$

58 Kyk Carl (2002: 40vv.) se onderskeid tussen "subject syllabus" en "subject curriculum" waar laasgenoemde 'n omvattende aanduiding is.

59 Vir' $n$ handige uiteensetting van die formaat van 'n sogenaamde "kursussillabus", kyk Gross Davis (2001:14-19). Haar boek kan as geheel met vrug deur dosente gebruik word. Dit gee riglyne wat bykans alle aspekte van die klaskamerpraktyk raak. 
Die artikulering van leeruitkomste trek prismaties bykans al die voorafgaande suggesties van hierdie artikel saam. Hier lê waarskynlik ook die grootste afwyking van dosering in 'n ouer paradigma. Wat hier geïdentifiseer word, beïnvloed die res van die komponente. Verder is hierdie moment van besondere belang veral in Suid-Afrika met die aanvaarding van Uitkomsgebaseerde Onderwys. ${ }^{60}$ As oorhoofse doelwit by die dosering van Dogmatiek moet die student begelei word om trinitaries-retories met die Christelike visie vir die Suider-Afrikaanse konteks om te gaan. Hierdie finale vaardigheid word slegs moontlik gemaak deur die verwerwing van 'n reeks ander spesifieke en konstituerende vaardighede. ${ }^{61}$ Veral vyf is ter sake: 'n Bybels-hermeneutiese, 'n konfessioneel-tradisionele, 'n retoriese, 'n kontekstueel-konstruktiewe en 'n trinitariese. Dogmatiek rus dus op inter-dissiplinêre samewerking met ander vakrigtings en veronderstel die dosering van sekere dissiplines wat in onguns verval het, byvoorbeeld retoriek. 'n Kursus in Dogmatiek steun op kennis en vaardighede in hermeneutiek, simboliek, retoriek, kontekstuele teologie, kulturele antropologie en $\mathrm{Pa}-$ tristiek. Wat hier voorgestel word is 'n afskeid van die praktyk wat op feitelike kennis en korttermyngeheue fokus en die verskuiwing na 'n dinamies-kreatiewe vaardigheid: 'n vermoë om trinitaries te dink, ${ }^{62}$ en om onverskrokke retories die Afrikawerklikheid hierby te betrek. Dat hier 'n ambisieuse projek verskuil lê, moet geensins verbloem word nie. Dat dit wesentlik by die Dogmatiek gaan om persoonsvorming, moet ingesien word. Om retories-trinitaries met die werklikheid om te gaan, is 'n wyse van dink en van leef. Dit veronderstel 'n fundamentele keuse van spiritualiteit. Wanneer Lindbeck $(1988: 12,16)$ pleit vir teologiese opleiding as geestelike vorming in die sin van "the internalization of a comprehensive and coherent religious outlook and correlated practices" is dit ook wat op die spel is, mutatis mutandis, by die dosering van Dogmatiek.

60 Kyk byvoorbeeld Van der Horst \& McDonald (2003).

61 Hier word spesifiek klem gelê op "vaardighede" om weg te doen met die klem op kennisoordrag. Daarmee word nie naïewelik beweer dat 'n bepaalde kennisinhoud nie vereis word nie. Kyk byvoorbeeld Donald (1986:271) wat beweer dat navorsing getoon het dat ten minste 100 nuwe konsepte nodig is vir die bemeestering van 'n kursus.

62 Gunton (2003:11) praat van "to think trinitarianly". 
Die keuse en seleksie van leerstof demonstreer waarskynlik op mees sigbare wyse die dilemma van die tydsgewrig. Die dae waar die leerinhoude bestaan het uit die voorskryf van 'n paar hoofstukke in 'n aantal standaard Europese teksboeke is finaal getel. Dit is juis die dinamika rondom seleksie en keuse wat uitermate geproblematiseer is: waarom Berkouwer en nie Mugambi nie? Waarom tekste en nie outobiogafiese vertellinge nie? ${ }^{63}$ Die waardes van die dogmatikus word hier onmisbaar gemanifesteer, want juis hierdeur geskied kontrole en legitimasie van gevestigde belange (Young 1975:103, 105). Die kategorie "leerstof" moet ruim verstaan word; dit sluit ook die identifisering van temas in. Om byvoorbeeld oor respek vir lewe te handel, mag vra om 'n teologie van die liggaam as veld van studie te identifiseer. Die uitdagings van Suider-Afrika lê die ontoereikende karakter van tradisionele dogmatiek bloot; byvoorbeeld, hóé en wáár word daar oor armoede en ekonomiese verontregting dogmatologies gehandel? Temas wat óf nog nooit werklik eksplisiet aangesny is nie, óf verwaarloos is, mag hulle aan die dogmatikus opdring. Die insluit van perspektiewe van die Ander het die moontlikheid om 'n verrykende tekstuur aan die keuse van leerstof te bring. Hoewel die hibridiese en kaleidoskopiese karakter van die sillabus aanvaar moet word, moet die soeke na integrasie nie sommer prysgegee word nie. Dit word in ooreenstemming met die gang van die hele argument deur twee realiteite bewerkstellig: enersyds deur' $n$ aandrang op identiteit wat gevorm word deur die trinitariese skopus en andersyds deur die strewe na relevansie met betrekking tot die konteks. My voorstel is dat laasgenoemde rondom die probleme van pluraliteit en verhoudinge, hulpbronne en armoede, en respek vir lewe kan wentel. Hierdie motiewe kan deurgaans aangespreek word, selfs indien die tradisionele loci-verdeling van die dogmatiek gevolg sou word. Dit handel ten diepste by leerstofseleksie om boustene vir 'n omvattende konstruksie van 'n simboliese wêreld waarin die Afrikarealiteit transformerend betrek kan word. Die taak van die dogmatikus is juis om hierdie probleme binne die breër raamwerk van eksistensieel-fenomenologiese vraagstukke trinitaries te behandel.

63 Slattery (1995:65) maak byvoorbeeld baie hiervan in die post-moderne kurrikulum. 
Die dae van die passiewe student as luisteraar is eweneens getel. Leerervarings, of leer- en doseermetodes, is onherroeplik gestempel deur 'n aantal ontwikkelings in die opvoedkunde. Die dogmatikus kan veel leer by die verskuiwing na 'n student-georiëntreerde paradigma, ${ }^{64}$ by die dissipline van volwasse leer, ${ }^{65}$ by probleem-gebaseerde leer ${ }^{66}$ en by die erkenning van multi-dimensionele intelligensie. ${ }^{67}$ Hierdie benaderings verruim die verskeidenheid van klaskamerpraktyke en open die moontlikheid van 'n ryke en opwindende verskeidenheid van aktiwiteite. Juis in Afrika is daar ' $n$ dringendheid om die diverse leerstyle van studente in ag te neem. ${ }^{68}$ Die klaskamerpraktyk moet normatief gestempel word deur die studie-onderwerp. Die kwaliteit van die trinitariese lewe - handhawing van Andersheid binne eenheid, van kreatiewe ekstase, van intersubjektiewe wedersydsheid - moet neerslag vind in die leer- en doseeraanpak. Verder moet die verskeidenheid van menslike vermoëns ontgin word om uitdrukking te gee aan die rykheid en skoonheid van God se lewe. Indien die klaskamer nie 'n oefen-laboratorium raak van diverse uitdrukkingsvorme van 'n basiese geloof en die implikasies daarvan nie, sal dieselfde armoede die bediening ook kenmerk. Indien dogmatisering 'n trinitaries-verbeeldende taak het, volg dit logieserwys dat leerervarings hierby moet aansluit. Kreatiewe uitdrukking behoort sentraal te staan by die aanleer van die vermoë om te teologiseer. Estetiese uitdrukking word selde benut as leermetode by die Dogmatiek en waarskynlik is dit ' $n$ veel gepaster wyse van reaksie op die skoonheid van die trinitariese lewe. 'n Nuwe situasie, polities, intellektueel en kerklik-teologies, moedig 'n nuwe klaskamerpraktyk aan waarvan baie dosente nie ervaring het nie. Dis nie meer 'n geval van die vertroude net oordra nie; kennis moet van nuuts af gekonstrueer word. Dosent en student sal saam die kruising van geloof en konteks moet verken en ontgin.

64 Die baanbreker artikel in hierdie verband was Barr \& Tagg (1995).

65 Kyk byvoorbeeld net die titel van die 1994 werk deur Vella, een van die groot kenners op hierdie gebied: Learning to listen, learning to teach.

66 Byvoorbeeld Savery \& Duffy (1998).

67 Die werk van Gardner (1983) is seminaal hieroor.

68 Die werk van Lingenfelter \& Lingenfelter (2003) besit veel wysheid wat met vrug gebruik kan word. Kyk veral die suggesties oor effektiewe doseermetodes in Afrika (p. 68). 


\section{KONKLUSIE: 'N TRINITARIESE EGGO}

Die voorgestelde verstaan van die taak van Dogmatiek en die benadering tot klaskamerpraktyk het ten doel om tot 'n bepaalde effek by te dra. 'n Trinitariese konsentrasie stel besondere intellektuele eise aan die teoloog wat onverminderd gehandhaaf moet word. Deur die geskiedenis van die kerk het die trinitariese diskoerse 'n vlak van rasionele sofistikasie aan Christelike teologie gegee wat maklik vervlak kan raak in 'n pragmatiese tydsgewrig. Die deurdenking van die misterie van God vereis intellektuele betrokkenheid wat die aanpak van ander vraagstukke op hul beurt met dieselfde kognitiewe kwaliteit mag informeer. Hier is 'n denkhouding ter sprake waarvan die invloed nie onderskat moet word nie. Soos verder aangetoon, is die trinitariese belydenis nie net 'n aanduiding van God se identiteit nie, maar ook van die diepste ontologiese bepaaldheid van die lewe. Skepping moet iets weerspieël van Skepper. Wat dit impliseer vir die verstaan van menswees, van kerk-wees, van mens-natuur/mens-mensverhoudinge, vir die aanwending van hulpbronne, en vir 'n samelewingstruktuur, moet teologies aangetoon word sodat 'n alternatiewe etos kan kristalliseer. Die oortuiging is dat die sentrale simbool van die kerk, van die Christelike geloof, potensiaal het om dominante Suider-Afrikaanse probleme van pluraliteit en verhoudinge, van ekonomiese dispariteit en dehumaniserende armoede, en minagting van lewe, te beïnvloed. As dogmatici en studente kan leer om kreatiefverbeeldende met hul konteks om te gaan, om vanuit hulle sentrale geloofsoortuiging te dink en te leef, moet daar geleidelik 'n nuwe ruimte ontstaan, 'n nuwe bewussyn en 'n nuwe spiritualiteit. 'n $\mathrm{Na}$ druklik trinitariese optiek in die Dogmatiek moet onvermydelik 'n stempel afdruk op ander teologiese dissiplines, op kerklike praktyk, en op publieke diskoers wat taalmatig bewussyn heroriënteer. Die hoop is dat iets van 'n lewegewende God, 'n ekstatiese God, 'n liefdevolle God, 'n relasionele God weerkaats mag word in die skepping. 


\section{BIBLIOGRAFIE}

\section{Avis P}

1999. God and the creative imagination. London: Routledge.

\section{BARR R R \& TAGG J}

1995. From teaching to learning. Change 27(6):13-25.

\section{BARTH K}

1975. Church Dogmatics 1/1. The doctrine of the Word of God. Edinburgh: T \& T Clark.

BAUM G (ED.)

1999. The twentieth century: a theological overview. Maryknoll, NY: Orbis.

\section{BAUMAN Z}

1987. Legislators and interpreters. Oxford: Polity.

1992. Intimations of postmodernity. London: Routledge.

\section{BERKHOF L}

1939. Systematic Theology. Grand Rapids: Eerdmans.

\section{BERNSTEIN R J}

1983. Beyond objectivism and relativism. Oxford: Blackwell.

\section{BHABHA H K}

1994. The location of culture. London: Routledge.

\section{Boff L}

1988. Trinity and society. Kent: Burns \& Oates.

\section{BRACKEN J A \& SUCHOKI M H (EDS.)}

1997. Trinity in process: a relational theology of God. New York: Continuum.

\section{BRUEGGEMANN W}

1997. Theology of the Old Testament. Minneapolis: Fortress.

2003. An introduction to the Old Testament. Louisville: Westminster John Knox.

\section{CARL A E}

2002. Teacher empowerment through curriculum development: theory into practice. 2nd ed. Lansdowne: Juta.

\section{CORNBLETH C}

1990. Curriculum in context. London: Falmer.

\section{$\mathrm{Cox} \mathrm{H}$}

1999. The myth of the twentieth century: the rise and fall of "secularization". In: G. Baum (ed.), The twentieth century: a theological overview (Maryknoll, NY: Orbis), pp. 135-143.

\section{CUNNINGHAM D S}

1990/1. Faithful persuasion. Notre Dame: University of Notre Dame Press. 1995. Trinitarian Theology since 1990. Reviews in Religion and Theology 4:8-16. 
1998. These Three are One. Oxford: Blackwell.

2003. The Trinity. In: Vanhoozer 2003:186-202.

D'Costa G

2000. Sexing the Trinity: gender, culture and the Divine. London: SCM.

DOLL W E JR.

1993. A post-modern perspective on curriculum. New York: Teachers College Press.

DONALD J G

1986. Knowledge and the university curriculum. Higher Education 15:267-282.

DOWNEY M

2000. Altogether gift: a trinitarian spirituality. Maryknoll, NY: Orbis.

Du TOIT C W (ED.)

2002. Research, identity and rationalism: thinking about research in Africa. Pretoria: UNISA.

EZE E C

1997. Introduction: philosophy and the (Post) colonial. In: E.C. Eze (ed.), Postcolonial African philosophy (Oxford: Blackwell), pp. 1-21.

\section{FORD D F}

2001. Radical orthodoxy and the future of British theology. ScJTh 54(3):385404.

FORD D F (ED.)

1997. The modern theologians. 2nd ed. Oxford: Blackwell.

\section{FOUCAULT M}

1970. The order of things. New York: Vintage.

\section{GARDNER H}

1983. Frames of mind: the theory of multiple intelligences. New York: Basic Books.

\section{GREEN G}

1989. Imagining God: theology and the religious imagination. Grand Rapids: Eerdmans.

\section{GRENZ S J}

2001. The social God and the relational self. Louisville: Westminster John Knox. 2004. Rediscovering the Triune God: the trinity in contemporary theology. Minneapolis: Fortress.

\section{Gross Davis B}

2001. Tools for teaching. San Francisco: Jossey-Bass.

\section{GuNTON C}

1997. The promise of trinitarian theology. 2nd ed. Edinburgh: T \& T Clark.

2003. Father, Son \& Holy Spirit: towards a fully trinitarian theology. London: T \& T Clark. 
GutiérRez G

1991. The God of life. Maryknoll, NY: Orbis.

\section{HeIM S M}

2001. The depth of the riches: a trinitarian theology of religious ends. Grand Rapids: Eerdmans.

\section{HeYNS J A}

1978. Dogmatiek. Pretoria: N G Kerkboekhandel Transvaal.

\section{HoBSBAwM E}

1994. The age of extremes: a history of the world, 1914-1991. New York: Vintage Books.

\section{Hunkins F P \& Hammill P A}

1995. Beyond Tyler and Taba: reconceptualzing the curriculum process. In: J.G. Haworth \& C.F. Conrad (eds), Revisioning curricula in Higher Education (London: Simon \& Schuster), pp. 16-25.

\section{HUNTINGDON S P}

1996. The clash of civilizations and the remaking of world order. London: Touchstone Books.

\section{JENSON R W}

1995. What is the point of trinitarian theology? In: Schwöbel 1995:31-43.

1997 \& 1999. Systematic Theology. Vol 1 \& 2. Oxford: Oxford University Press.

\section{KASPER W}

1983. The God of Jesus Christ. London: SCM.

\section{KAUFMANN G F}

1979. An essay on theological method. Rev. ed. Atlanta: Scholars Press.

\section{KEARNEY R}

1988. The wake of imagination. London: Routledge.

\section{KELLY A V}

1989. The curriculum: theory and practice. 3rd ed. London: Paul Chapman.

\section{KUHN T S}

1970. The structure of scientific revolutions. 2nd ed. Chicago: University of Chicago Press.

\section{LACUGNA C M}

1991. God for us: the trinity and Christian life. San Francisco: Harper.

\section{LEE J Y}

1996. The trinity in Asian perspective. Nashville: Abingdon.

\section{LEFEBVRE H}

1991. The production of space. Oxford: Blackwell. 


\section{LINDBECK G}

1984. The nature of doctrine. Philadelphia: Westminster.

1988. Spiritual formation and theological education. Theological Education 24 (Suppl. 1):10-31.

\section{LINGENFELTER J E \& LINGENFELTER S G}

2003. Teaching cross-culturally: an incarnational model for learning and teaching. Grand Rapids: Baker.

LYOTARD J-F

1984. The postmodern condition: a report on knowledge. Manchester: Manchester University Press.

\section{MacPherson E D}

1995. Chaos in the curriculum. Journal of Curriculum Studies 27(3):263-279.

\section{MARSHALl B D}

2000. Trinity and truth. Cambridge: Cambridge University Press.

\section{Mвіті J S}

1991. Introduction to African religion. 2nd ed. Nairobi: E.A.E.P.

\section{MeEKs M D}

1980. Towards a Trinitarian view of economics. Christianity and Crisis 40:307-316. 1989. God the economist: the doctrine of God and political economy. Minneapolis: Fortress.

\section{MURPHY N C}

1994. Reasoning and rhetoric in religion. Valley Forge: Trinity Press International.

\section{NiCHOLLS D}

1989. Deity and domination. London: Routledge.

\section{NYAMITI C}

1977. African tradition and the Christian God. Eldoret, Kenya: Gaba Publications. 1985. The trinitarian foundation of the church's teaching on Christian marriage and sexual ethics. African Christian Studies (1/2):70-92.

1987. Ancestral kinship in the trinity: an African theology of the trinity. In: A.A.R. Crollius (ed.), Inculturation: working papers on living faith and cultures 9 (Rome: Pontifical Gregorian University), pp. 31-48

1988. The naming ceremony in the trinity: an African onomastic approach to the trinity. African Christian Studies 4(1\&3):41-73, 55-83.

1996. The trinity from an African ancestral perspective. African Christian Studies 12(4):38-74.

1998. Divine immanent responsibility: an African approach to the mystery of the trinity. African Christian Studies 14(4):1-45.

1999. The trinity as source and soul of African family ecclesiology. African

Christian Studies 15(1):34-92. 
O'Collins G

1999. The Holy Trinity: the state of the questions. In: S. Davis et al., The trinity (Oxford: Oxford University Press), pp. 1-25.

Olson R E \& Hall C A 2002. The trinity. Grand Rapids: Eerdmans.

Ornstein A C \& Hunkins F

1988. Curriculum: foundations, principles $\mathcal{E}$ theory. 2nd ed. Boston: Allyn \& Bacon.

PANNENBERG W

1991. The Christian vision of God: the new discussion on the trinitarian doctrine. Trinity Seminary Review 13:53-60.

\section{Peters T}

1993. God as trinity. Louisville: Westminster John Knox.

\section{PINAR W F}

1979. The reconceptualization of curriculum studies. In: P.H. Taylor (ed.), New directions in curriculum studies (London: Falmer), pp. 13-22.

\section{RAHNER K}

1970 [1997]. The trinity. New York: Crossroads.

\section{RORTY R}

1998. Truth and progress: philosophical papers vol. 3. Cambridge: Cambridge University Press.

\section{SAID E W}

2003 [1978, 1995]. Orientalism. London: Penguin.

\section{SAVERY J R \& DUFFY T M}

1998. Problem-based learning: an instructional model and its constructivist framework. In: R. Fogarty (ed.), Problem-based learning (Arlington Heights: Skylight), pp. 73-92.

\section{SCANLON M J}

1987. The linguistic turn. In: G. Kilcourse (ed.), The linguistic turn and contemporary theology (The Catholic Theological Society of America), pp. vii-x.

1999. The postmodern debate. In: Baum 1999:228-237.

\section{SCHILDER A}

1987. Hulpeloos maar schuldig. Kampen: Kok.

\section{SCHIPPER M}

1999. Imagining insiders: Africa and the question of belonging. London: Cassell.

\section{SCHLEIERMACHER F}

1928 [1976]. The Christian faith. Edinburgh: T \& T Clark. 


\section{SCHÜSSLER FIORENZA E}

1988. The ethics of Biblical interpretation: decentering Biblical scholarship. JBL 107(1):3-17.

SCHWÖBEL C (ED.)

1995. Trinitarian theology today. Edinburgh: T\&T Clark.

1995. The Renaissance of trinitarian theology. In: Schwöbel 1995:1-30.

SLATTERY P

1995. Curriculum development in the postmodern era. New York: Garland Publishing.

\section{SOJA E W}

1996. Third space. Oxford: Blackwell.

\section{TANNER K}

1997. Theories of culture: a new agenda for theology. Minneapolis: Fortress.

\section{TANNER D \& TANNER L}

1995. Curriculum development: theory into practice. 3rd ed. Englewood Cliffs: Prentice Hall.

\section{THEISSEN G}

1999. The religion of the earliest churches: creating a symbolic world. Minneapolis: Fortress.

\section{THOMPSON J}

1994. Modern trinitarian perspectives. Oxford: Oxford University Press.

\section{THOMPSON T R}

1996. Imitatio trinitatis: the trinity as social model in the theologies of Jürgen Moltmann and Leonardo Boff. Princeton: Unpublished Ph.D. dissertation.

1997. Trinitarianism today: doctrinal renaissance, ethical relevance, social redolence. CJT 32:9-42.

\section{TRACY D}

1994a. The return of God in contemporary theology. Concilium 1994(6):37-46. 1994b. Theology and the many faces of postmodernity. ThT 51(1):104-114. 1999. Fragments: the spiritual situation of our times. In: J.D. Caputo \& M.J. Scanlon (eds.), God, the gift and postmodernism (Bloomington: Indiana University Press), pp. 170-181.

\section{TYLER R W}

1949. Basic principles of curriculum and instruction. Chicago: University of Chicago Press.

\section{USHER R \& EDWARDS R}

1994. Postmodernism and education. London: Routledge.

\section{VAN DER Horst H \& MCDONALD R}

2003. Outcomes-based education: theory and practice. Irene: Tee Vee. 


\section{Van Genderen J \& Velema W H}

1992. Beknopte gereformeerde Dogmatiek. Kampen: J H Kok.

\section{VANHOOZER K J}

1998. Is there a meaning in this text? Grand Rapids: Zondervan.

2003b. Theology and the condition of postmodernity: a report on knowledge (of God). In: Vanhoozer 2003a:3-25.

\section{VANHOOZER K J (ED.)}

1997. The trinity in a pluralistic age. Grand Rapids: Eerdmans.

2003a. The Cambridge companion to postmodern theology. Cambridge: Cambridge University Press.

\section{VELLA J}

1994. Learning to listen, learning to teach: the power of dialogue in educating adults. San Francisco: Jossey-Bass.

\section{VOLF M}

1998. After our likeness: the church as the image of the trinity. Grand Rapids: Eerdmans.

\section{WALLS A F}

2002. The cross-cultural process in Christian history. Maryknoll, NY: Orbis.

\section{WATSON P}

2000. A terrible beauty: a bistory of the people and ideas that shaped the modern mind. London: Weidenfeld \& Nicolson.

\section{WeBB S H}

1996. The gifting God. Oxford: Oxford University Press.

\section{WILLIAMS R}

2000. On Christian theology. Oxford: Blackwell.

\section{Young M F D}

1975. An approach to the study of curricula as socially organized knowledge. In: M. Golby, J. Greenwald \& R. West (eds.), Curriculum design (London: Croom Helm), pp. 100-127.

Trefwoorde

Dogmatiek

Suider-Afrika

Onderrig

Drie-Eenheid
Keywords

Systematic Theology

Southern Africa

Teaching

Trinity 